Note

\title{
A Case of Autoimmune Hypophysitis Associated with Asymptomatic Primary Biliary Cirrhosis
}

\author{
MASATERU NISHIKI, YoSHIO MURAKAMI, KUNIO KOSHIMURA, MotoI SOHMIYA, \\ JUNKO TANAKA, SHIGEKI YABE*, ISAO KOBAYASHI* AND YUZURU KATO \\ First Division, Department of Medicine, Shimane Medical University, Shimane 693-8501, and \\ *Department of Laboratory Medicine and Clinical Laboratory Center, Gunma University School of Medicine, \\ Gunma 371-8511, Japan
}

\begin{abstract}
We report a 61-year old male patient with panhypopituitarism complicated with asymptomatic primary biliary cirrhosis (PBC). T1-weighted magnetic resonance imaging demonstrated high intensity of the anterior pituitary gland. There was no mass lesion or enlargement of the pituitary gland or the stalk. Immunoblot analysis of the patient's sera with rat pituitary antigens revealed a band with a molecular size of $22 \mathrm{kD}$. Anti- $\mathrm{M}_{2}$ mitochondrial antibody has been consistently positive for five years. Liver biopsy revealed portal hepatitis with periportal infiltration of the inflammatory cells. This is the first case report of autoimmune hypophysitis complicated with asymptomatic PBC.
\end{abstract}

Key words: Anti-pituitary antibody, Anti-mitochondrial antibody, Asymptomatic primary biliary cirrhosis, Hypopituitarism

(Endocrine Journal 45: 697-700, 1998)

IT HAS been reported that autoimmune hypophysitis was often complicated with other autoimmune diseases such as chronic thyroiditis [1]. It is also known that a variety of organ-specific autoantibodies are detected in the sera of patients with autoimmune hypophysitis. There have been several cases with positive anti-mitochondrial antibody [2, 3], but its pathophysiological significance has not been elucidated. Antimitochondrial antibody is highly specific for primary biliary cirrhosis (PBC). Especially anti- $\mathrm{M}_{2}$ mitochondrial antibodies are most often found in patients with clinical $\mathrm{PBC}[4,5]$. In this paper, we report an elderly male patient with autoimmune hypophysitis associated with asymptomatic PBC which was ascertained by the liver biopsy.

Received: March 20, 1998

Accepted: July 10, 1998

Correspondence to: Dr. Masateru NISHIKI, First Division, Department of Medicine, Shimane Medical University, 891 Enyacho, Izumo 693-8501, Japan

\section{Case Report}

A 56-year old man was admitted to a hospital after an episode of palpitation, cold sweating and weakness five years earlier. Hypotension and hypoglycemia were relieved by treatment with hydrocortisone, and the patient was transferred to our hospital for further examination.

On physical examination, his blood pressure was $90 / 68 \mathrm{mmHg}$, and pulse rate was $64 / \mathrm{min}$, regular. The visual field and the acuity were normal. Goiter was not palpable. Axillary and pubic hair distributions were normal.

Hematological and biochemical laboratory data showed no remarkable abnormalities except mild anemia (Hb: $11.8 \mathrm{~g} / \mathrm{d} l$ ). Serum electrolyte and transaminoferase levels were within normal limits. Endocrinological tests revealed impaired secretion of ACTH, GH, PRL and gonadotropins (Table 1, Fig. 1). Diabetes insipidus was not present. Serum anti-mitochondrial antibody was positive at a 
dilution of 1:160 by immunofluorescence. Serum IgM and IgG anti- $\mathrm{M}_{2}$ mitochondrial antibodies were $700 \mathrm{U} / \mathrm{ml}$ and $368 \mathrm{U} / \mathrm{ml}$, respectively as

Table 1. Laboratory findings on admission

\begin{tabular}{|c|c|c|c|}
\hline & Aldosterone & $3.8 \mathrm{ng} / \mathrm{d} l$ \\
\hline \multirow{3}{*}{$\begin{array}{l}\text { Endocrine } \\
\text { GH } \\
\text { urine GH } \\
\text { IGF-I }\end{array}$} & $<0.3 \mathrm{ng} / \mathrm{ml}$ & urine $17 \mathrm{OHCS}$ & $0.6 \mathrm{mg} /$ day \\
\hline & $3.3 \mathrm{pg} / \mathrm{mgCr}$ & urine $17 \mathrm{KS}$ & $1.8 \mathrm{mg} /$ day \\
\hline & $27 \mathrm{ng} / \mathrm{ml}$ & Immunology & \\
\hline PRL & $2.4 \mathrm{ng} / \mathrm{ml}$ & C3 & $51 \mathrm{mg} / \mathrm{d} l$ \\
\hline $\mathrm{ADH}$ & $1.1 \mathrm{pg} / \mathrm{ml}$ & $\mathrm{C} 4$ & $41.9 \mathrm{mg} / \mathrm{d} l$ \\
\hline TSH & $6.5 \mu \mathrm{U} / \mathrm{ml}$ & $\mathrm{CH} 50$ & $34.5 \mathrm{U} / \mathrm{ml}$ \\
\hline T3 & $120 \mathrm{ng} / \mathrm{d} l$ & IgG & $1149 \mathrm{mg} / \mathrm{d} l$ \\
\hline $\mathrm{T} 4$ & $6.6 \mu \mathrm{g} / \mathrm{d} l$ & IgM & $166 \mathrm{mg} / \mathrm{d} l$ \\
\hline Free T4 & $0.8 \mathrm{ng} / \mathrm{d} l$ & IgA & $277 \mathrm{mg} / \mathrm{dl}$ \\
\hline LH & $3.2 \mathrm{mIU} / \mathrm{ml}$ & AMA & $\times 160$ \\
\hline FSH & $3.1 \mathrm{mIU} / \mathrm{ml}$ & anti-M $\mathbf{M}_{2} \operatorname{IgM}$ & $700 \mathrm{U} / \mathrm{ml}$ \\
\hline Testosterone & e $328 \mathrm{ng} / \mathrm{d} l$ & anti-M $\mathrm{M}_{2} \operatorname{IgG}$ & $368 \mathrm{U} / \mathrm{ml}$ \\
\hline ACTH & $11 \mathrm{pg} / \mathrm{ml}$ & TGHA & $<\times 100$ \\
\hline Cortisol & $0.37 \mu \mathrm{g} / \mathrm{d} l$ & MCHA & $<\times 100$ \\
\hline
\end{tabular}

17OHCS, 17-hydroxycorticosteroids; 17KS, 17-ketosteroids; AMA, anti-mitochondrial antibody; anti- $\mathrm{M}_{2}, \mathrm{M}_{2}$ type of AMA; TGHA, anti-thyroglobulin antibody; MCHA, anti-microsomal antibody. determined by enzyme immunoassay [6]. Antipituitary antibody was examined by immunoblot analysis as previously described by Yabe et al. [7]. As shown in Fig. 2, a major band was identified at $22 \mathrm{kD}$. A minor band also was seen at $49 \mathrm{kD}$, presumably due to anti- $\mathrm{M}_{2}$ mitochondrial antibody.

T1-weighted image of magnetic resonance imaging (MRI) demonstrated a heterogenous high intensity in the anterior lobe of the pituitary gland. The posterior lobe and the stalk were normal (Fig. $3)$.

This patient has been treated with hydrocortisone for five years. During the treatment, daily excretion of urinary 17-OHCS remained within the normal range, and neither clinical signs nor laboratory findings indicated adrenal insufficiency. Serum transaminoferase levels remained within normal limits. Serum IgM $(1256 \mathrm{U} / \mathrm{ml})$ and $\operatorname{IgG}(605 \mathrm{U} /$ $\mathrm{ml}$ ) anti- $\mathrm{M}_{2}$ mitochondrial antibodies were consistently high.

Liver biopsy was performed to evaluate the liver histology and revealed portal hepatitis with periportal infiltration of inflammatory cells (Fig.
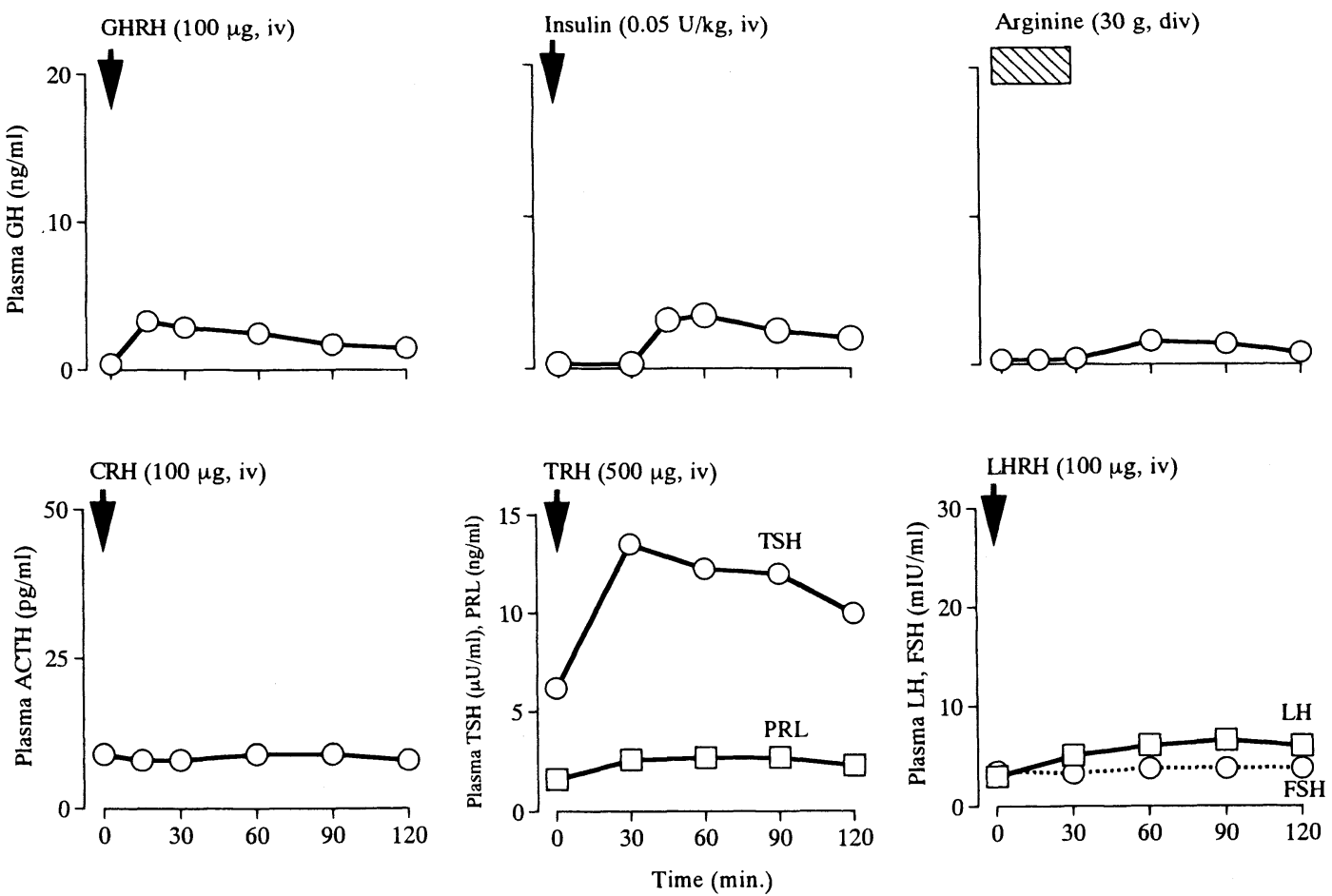

Fig. 1. Endocrinological provocative tests. Upper pannels; plasma GH responses to GHRH, insulin-induced hypoglycemia and arginine. Lower pannels; plasma ACTH, TSH and prolactin, and gonadotropin response to CRH, TRH and LHRH, respectively. 


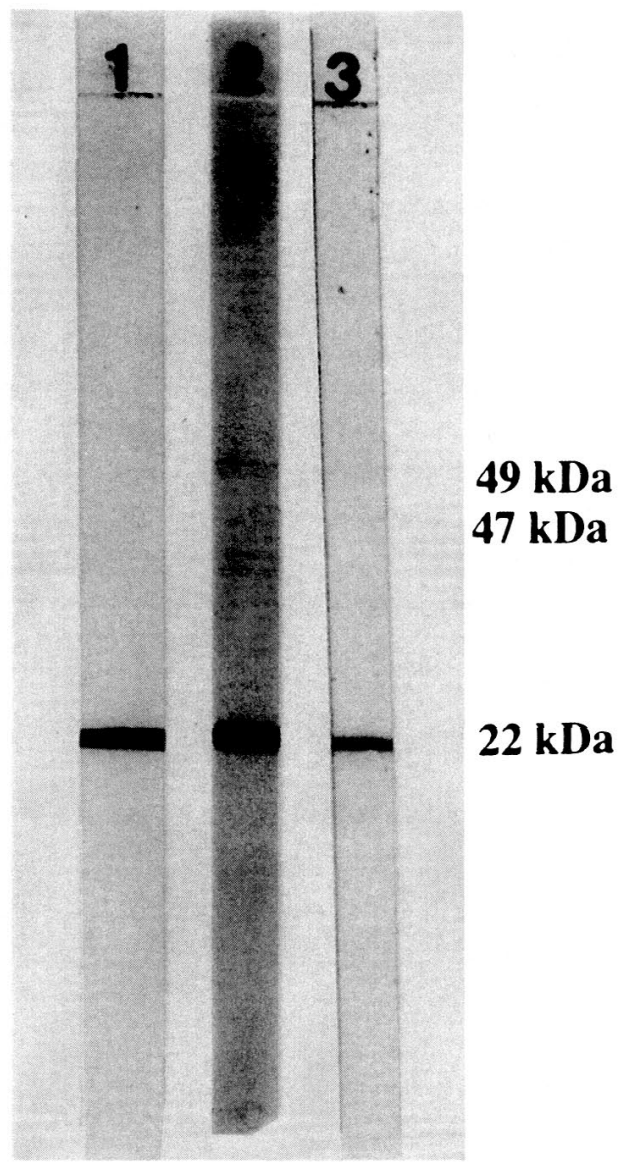

Fig. 2. Immunoblot analysis of the patient's sera with rat pituitary antigens. Rat pituitary antigens were electrophoresed in polyacrylamide gel, transferred to a PVDF membrane, and were reacted with the patient's serum (dilution; 1: 101), followed by the avidin biotin peroxidase complex method. Lane 1: positive control serum, Lane 2: patient's serum (February 1992), Lane 3: patient's serum (January 1996).

4). No granulomatous lesion or inflammatory destruction of bile ducts was found. These findings correspond to the portal stage of $\mathrm{PBC}$ according to morphologic staging described by Ludwig et al. [8].

\section{Discussion}

Autoimmune hypophysitis is characterized by lymphocytic infiltration into the pituitary gland [2, 3] and by the presence of anti-pituitary antibody in the serum $[7,9,10]$. In the present case, the detection of anti-pituitary antibody by a

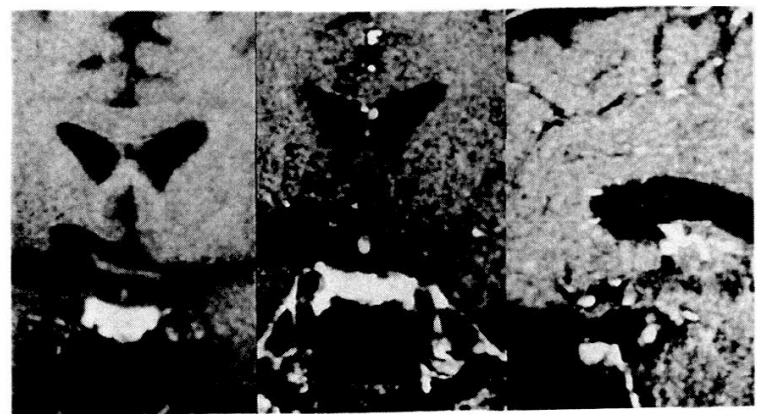

Fig. 3. T1-weighted MRI images. Left: coronal, plain Middle: coronal, gadolinium (Gd) enhancement Right: sagittal, Gd enhancement. Note the high intensity in the anterior pituitary gland. No enlargement of the pituitary gland or the stalk was found.

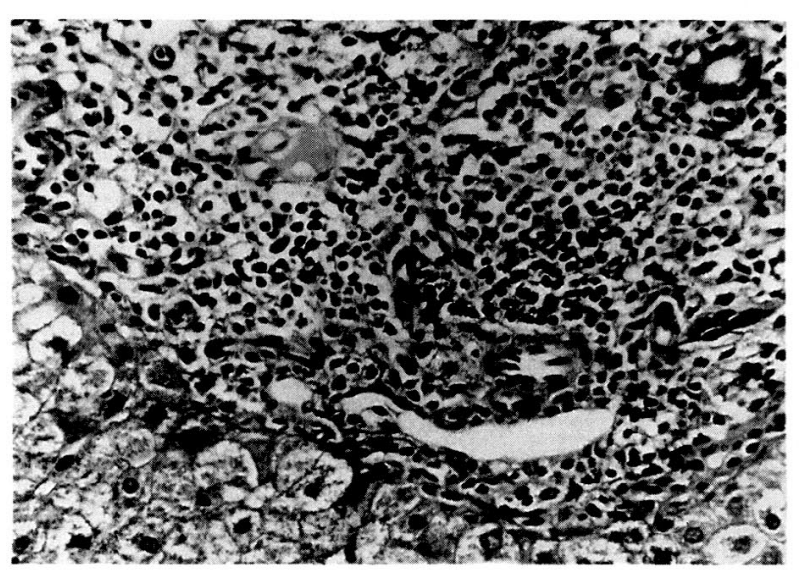

Fig. 4. Histology of the liver $(x 400)$ shows periportal infiltration of inflammatory cells. No granuloma or destruction of bile ducts was found.

conventional immunofluorescence method was interfered by an anti-mitochondrial antibody, but immunoblotting with antigens of rat pituitary gland revealed an antibody to the antigen with a molecular size of $22 \mathrm{kD}$.

Anti- $\mathrm{M}_{2}$ mitochondrial antibody was consistently positive in the present case. Nine types of antimitochondrial antibody $\left(\mathrm{M}_{1}-\mathrm{M}_{9}\right)$ have been described. Among them, anti- $\mathrm{M}_{2}$ mitochondrial antibody is the most specific for PBC $[4,5]$. There have been several case reports of autoimmune endocrine diseases associated with positive antimitochondorial antibodies. Perros et al. [11] reported two patients with Graves' disease in whom 
anti-mitochondrial antibody was detected. In these patients, anti- $\mathrm{M}_{2}$ mitochondrial antibody was negative and there was no liver dysfunction. A few autoimmune hypophysitis patients with positive anti-mitochondrial antibody have been described $[2,3]$, but no detailed information on antibody subtypes, liver function or histology is available.

Portal hepatitis with periportal inflammation was demonstrated in the liver biopsy in the present case. Neither ganuloma nor nonsuppurative destructive cholangitis was noted. According to the morphological staging by Ludwig et al. [8], these findings correspond to portal stage of PBC. Anti$\mathrm{M}_{2}$ mitochondrial antibody of the IgM type is generally found in patients with asymptomatic $\mathrm{PBC}$, and seroconversion from IgM to IgG antibody often indicates progression of the disease $[5,6]$. In our patient, no clinical liver dysfunction has been found during the clinical course for five years. This might be related to the fact that IgM anti- $\mathrm{M}_{2}$ mitochondrial antibody has been positive without seroconversion to IgG type. Although asymptomatic $\mathrm{PBC}$ patients usually have a favorable prognosis, it sometimes takes more than ten years for the asymptomatic PBC to develop into the stages of advanced histologic lesions and clinical liver dysfunctions [12].

In summary, we report an old male case of lymphocytic hypophysitis complicated with asymptomatic PBC. Anti-pituitary antibody and anti-mitochondrial antibody were demonstrated in the serum. Histopathological examination of the liver demonstrated portal hepatitis with periportal inflammation. These findings suggest that anti- $\mathrm{M}_{2}$ mitochondrial antibody might have pathophysiological significance in this patient with autoimmune hypophysitis in the development of PBC.

\section{Acknowledgments}

This work was supported in part by grants from the Ministry of Health and Welfare, Japan.

\section{References}

1. Hashimoto $K$, Takao $T$, Makino $S$ (1997) Lymphocytic adenohypophysitis and lymphocytic infundibuloneurohyophysitis. Endocr J 44: 1-10.

2. Cosman F, Post DK, Holub AD, Wardlaw LS (1989) Lymphocytic hypophysitis. Report of 3 new cases and review of the literature. Medicine 68: 240-256.

3. Thodou E, Asa SL, Kontogeorgos G, Kovacs K, Horvath E, Ezzat S (1995) Clinical case seminar: Lymphocytic hypophysitis: Clinicopathological findings. J Clin Endocrinol Metab 80: 2302-2311.

4. Berg PA, Klein R, Lindenborn-Fotinos J (1986) Antimitochondrial antibodies in primary biliary cirrhosis. J Hepatology 2: 123-131.

5. Berg PA, Klein R (1986) Mitochondrial antigens and autoantibodies: From anti-M $\mathrm{M}_{1}$ to anti-M. Klin Wochenschr 64: 897-909.

6. Plebani M, Chiaramonte $M$, Floreani A, Bertorelle R, Naccarato R, Burlina A (1989) Two new serum immunoassay (RIA and EIA) for the determination of $\mathrm{M}_{2}$ antimitochondrial antibodies in primary bilary cirrhosis. Clinica Chimica Acta 181: 201-206.

7. Yabe S, Murakami M, Maruyama K, Miwa $H$, Fukumura Y, Ishii S, Sugiura M, Kobayashi I (1995) Western blot analysis of rat pituitary antigens recognized by human antipituitary antibodies. Endocr J 42: 115-119.

8. Ludwig J, Dickson ER, McDonald GSA (1978) Staging of chronic nonsuppurative destructive cholangitis (Syndrome of primary biliary cirrhosis). Virchows Arch (Pathol Anat) 379: 103-112.

9. Bottazzo GF, Pouplard A, Florin-Christensen A, Doniach D (1975) Autoantibodies to prolactinsecreting cells of human pituitary. Lancet 2: 97-101.

10. Sugiura M, Hashomoto A, Shizawa M, Tsukada $M$, Maruyama S, Ishida T, Kasahara T, Hirata Y (1986) Heterogeneity of anterior pituitary cell antibodies detected in insulin dependent diabetes mellitus and adrenocorticotropic hormone deficiency. Diabetes Res 3: 111-114.

11. Perros $P$, Palmer JM, Yeaman SJ, Kendall-Taylor $P$ (1994) Anti-mitochondrial antibodies in patients with Graves' disease may not signify primary biliary cirrhosis. Postgrad Med J 70: 17-18.

12. Fleming CR, Scheuer PJ, Sherlock S (1978) Asymptomatic primary biliary cirrhosis. Presentation, histology and results with dpenicillamine. Mayo Clin Proc 53: 587-593. 